\title{
Study on the Selection Determinants on Consumers Purchasing Agricultural Products via Direct Market*
}

\author{
Jae-Wan LEE ${ }^{1}$, Jae-Jin KIM² \\ 1 First Author Assistant Professor, Department of Law and Police Administration, Hoseo University, Korea \\ E-mail: noso791@hoseo.edu \\ 2 Corresponding Author Assistant Professor, School of Business Administration, Hoseo University, Korea \\ E-mail: jkim@hoseo.edu
}

Received: 22 August 2020. Revised: 14 September 2020. Accepted: 16 September 2020

\begin{abstract}
Purpose - This study was carried out to analyze the influential factors of how consumers methodize purchasing agricultural products via direct market. It further utilizes the Discrete Choice Model to analyze consumer decision specifically with regards to individual markets and store attributes.

Research design and methodology - This study will use the multinomial logit model to interpret the influential factors behind selecting a specific market to purchase from. This study establishes 'online direct-purchase' as the base category with 'direct farm markets', 'local foods direct markets', 'produce boxes (CSA)' as substitutes.

Results - Firstly, the variety of products, price and freshness had a positive influence on choosing 'direct farm markets' while convenience of payment and transportation had a negative influence. Second, freshness and store attributes had a positive influence on choosing 'local foods direct markets' but product price and packaging, location accessibility had a negative influence. And although product creditability had a positive influence on purchasing 'produce boxes (CSA)', product price had a negative influence.

Conclusions - Accordingly, there is a need for the South Korean government to encourage the adoption of mobile payment through smartphone applications in direct farm markets to vitalize direct agricultural purchasing. However, this does need to be approached cautiously as price has a conflicting affect for each method of purchase.
\end{abstract}

Keywords: Direct-Purchase of Agricultural (Fresh) Produce, Discrete Choice Model

JEL Classification Code: M30, M31, Q18

\footnotetext{
* This work was supported by the Ministry of Education of the Republic of Korea and the National Research Foundation of Korea (NRF-201 9S1A5A8038762)

(c) Copyright: The Author(s)

This is an Open Access article distributed under the terms of the Creative Commons Attribution Non-Commercial License (http://Creativecommons.org/licenses/by-nc /4.0/) which permits unrestricted noncommercial use, distribution, and reproduction in any medium, provided the original work is properly cited.
} 


\section{Introduction}

The purpose of this study is to analyze the methodology of consumers selecting agricultural produce directpurchase channels and the related influential factors surrounding their choices. It further analyzes the nature of each market, or in other words product and store attributes, for directly purchasing fresh produce. The data from

$\ulcorner$ Research on Policy Perception of the Agricultural Produce Direct-Purchase Policy $\lrcorner$ conducted by the Ministry of Agriculture, Food and Rural Affairs with solicitation from Focus Company was used in this study.

The majority of fresh produce is manufactured in rural areas then consumed in metropolitan areas. The territorial gap between area of production and area of consumption has developed distribution systems such as wholesalers, wholesale intermediaries, retailers, etc. However, complicated distribution systems not only give rise to economic inefficiencies such as increase in logistical cost and decrease in freshness but also cause consumers to feel uncertain about the stability of the produce. (Lee \& Lee, 2016).

Due to said issues, fresh produce direct-purchase, which mitigates the complication of these distribution systems and provides reasonable prices for both the producer and consumer by reducing distribution costs, is being proactively implemented. The South Korean government has actively established and cultivated new distribution channels for agricultural produce such as local food direct markets, produce boxes, direct farm markets and online stores since 2013 (The Farmers Newspaper, 2015). Resultantly, direct sales of agricultural products amounted to 1.8192 trillion KRW in 2014, which was a $33.3 \%$ increase from its 1.3647 trillion KRW record in 2012, and logistic cost savings increased twofold from 291.9 billion KRW in 2012 to 624 billion KRW in 2014 (Korea JoongAng Daily, 2015). Also, with focus on the 2015 report of fresh produce direct-purchase, online shopping constituted the largest portion with 1.2347 trillion KRW followed by local foods direct markets (209.5 billion KRW), direct farm markets (178.7 billion KRW) and produce boxes (16.9 billion KRW) (MAFRA, 2016b).

With this, the government initiated the 'Policy Statement to Revitalize Direct Trade in Agricultural Products, including Promotion of Use of Local Agricultural Products' in November 2016 with intention to provide an agricultural distribution system that both producers and consumers can trust and rely on. As stable establishment of a new distribution channel being the essence of the policy statement, the government is pursuing various measures such as vitalizing online direct market through building a farm market database, improving management of local foods direct markets, establishing a standard model of direct-purchase markets by regulating and systemizing and stimulating usage of produce boxes and community-supported agriculture (CSA) (MAFRA, 2016b). Accordingly, each local government is either building local direct-purchase markets and local produce distribution systems or expanding methods for the entities of metropolitan areas and rural areas to coexist in terms of urban-rural exchange (Korea Food Service News, 2019). Nevertheless, these policy efforts are but governmentled means of support based from simply collecting feedback and is, to an extent, far from being evidence-based policies that have undergone strict empirical analyses.

Previous studies concerning fresh produce direct market can be divided as either a producer-centered approach or a consumer-centered approach. The producer-centered approach analyzes distribution channel selection in terms of marketing strategy and views economic, institutional, technical and social variables as major influencing factors (Udimal, 2015). The consumer-centered approach, on the other hand, analyzes preference of transaction methods and views demographic, socio-economic factors, product quality and credibility as major influencing factors (Rehman \& Selvaraj, 2016). However, the above said studies are limited to mostly focusing on the selection between existing distribution channels and direct-purchase channels while not touching upon the various methods that influence the selection of direct-purchase specifically.

Thus, this study tries to analyze the factors that influence the consumers' choices through the multinomial choice model. Hence, through the multinomial logit model, this study will explore the elements that determine the selection of agricultural produce direct-purchase channel.

\section{Literature Review and Prior Research}

\subsection{Background on Agricultural Produce Direct Market}

\subsubsection{Definition of Agricultural Produce Direct Market}

The concept of agricultural product direct marketing has been defined by scholars in various ways. According to the $\ulcorner$ Farmer-to-Consumer Direct Marketing Act $\lrcorner$ passed in 1976 in the United States of America, direct marketing is defined as "the marketing of agricultural commodities from a producer or producer group to a consumer or consumer group in a manner calculated to lower the cost and increase the quality of food while providing increased financial returns to the farmers" (Lee, 2009). Article 2 of Korea's $\ulcorner$ Act on Revitalization of 
Direct Trade in Agricultural Products, including Promotion of Use of Local Agricultural Products $\lrcorner$, legislated in 2015, defines the direct trading agricultural products as "direct trade between producers and consumers or trade undergoing only one intermediary distribution stage." The idea of direct trade in agricultural products first appeared in the 1930s during America's Great Depression where farmers started gaining interest in selling produce in the streets. Direct market of fresh produce originated in a farmer's market on Gilmore Ranch in 1934 where farmers sold produce directly from their trucks to local residents (Rehman \& Selvaraj, 2013). In Korea, the term surfaced in 1998 as part of the Agricultural Product Distribution Reformation to diversify distribution channels and reduce distribution margins (Kim \& Park, 2012).

Such direct transactions between producers and consumers and the decrease of intermediary distributors not only provides financial benefits for both parties but also promotes urban-rural exchange which in turn socially and economically vitalizes rural communities (Lee \& Lee, 2016).

\subsubsection{Methods of Agricultural Produce Direct Market}

The types of agricultural produce direct market can be classified by various criteria. Generally, in Korea, it is divided into two large categories of face-to-face transactions and order transactions; face-to-face transactions are composed of permanent and temporary stores (Kim, Kim, Jung et al. 1999). With the development of information and communication technology (ICT) and internet these traditional brick-and-mortar businesses have somewhat vanished and gave way to a new category. This new classification subcategorizes, based on transaction method and regional scope, into four channels comprising of offline direct farm markets, local foods direct markets, Community Supported Agriculture's seasonal produce boxes and online direct markets (MAFRA, $2016 \mathrm{~b}$ ).

Direct farm markets are a type of market where farmers sell produce and processed goods in temporary buildings like tents, at regular intervals of time; representative examples of this would be Anseong Early Morning Market, Gwacheon Baro Market and Gumi Geumosan Wholesale Market. Local foods direct markets are where the farmers harvest, package, price, manage inventory and sell directly via their own store to local consumers; representative would be Yeosu Nonghyup Direct Market, Yongjin Nonghyup Direct Market and Wanju Local Food Cooperative. And (seasonal) produce boxes are periodical subscription packages available with a membership fee and prior agreement with the farmer; examples would be Sister's Garden (Korean Women Peasant's Association), Mom's Garden Produce Boxes and Heuksalim. Lastly, online direct market is a method in which farmers or agricultural organizations operate online websites to sell produce untact to consumers; examples would be Jeonnam's Jbplaza, e-Gyeongnam mall and Pohang Market (MAFRA, 2016b).

In order to maximize socio-economic benefits of agricultural direct market, the government has been introducing regulatory reforms such as lowering credit card processing fees in local foods direct markets, allowing gift certificates in direct farms markets, giving income tax reductions on produce bought in direct markets and setting up markets in areas near riversides and parks (MAFRA, 2017). However, it can be said that this policylevel amending is not based on rigid empirical analysis.

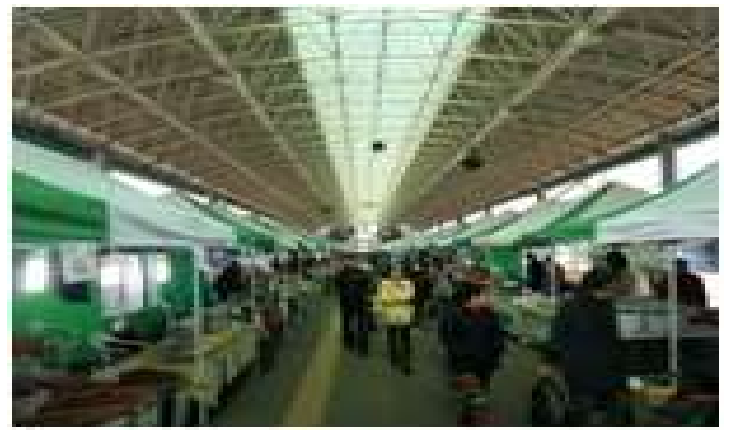

$<$ Direct Farm Markets (Gwacheon Baro Market)>

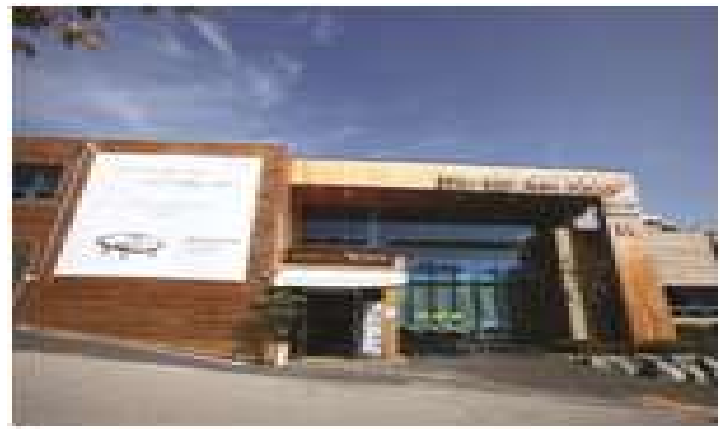

$<$ Local Foods Direct Market (Wanju Local Food Cooperative) $>$ 


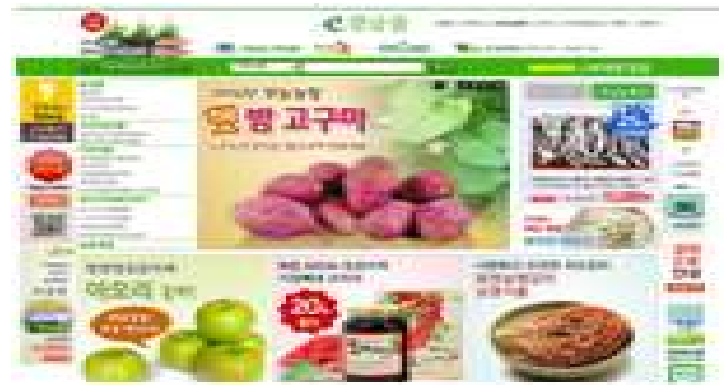

Online Direct Market (e-Gyeongnam Mall) Source: MAFRA (2016a).

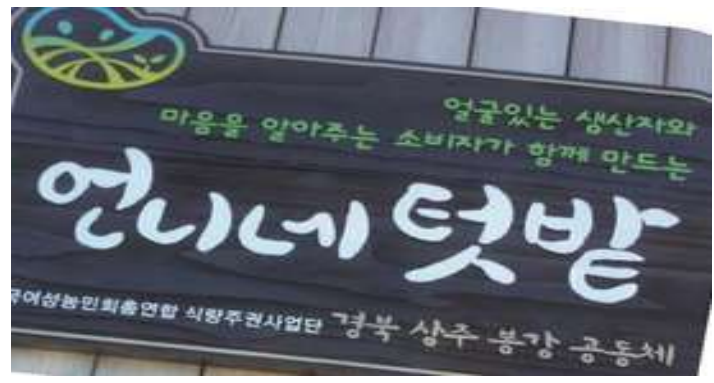

Produce Box Scheme (Sister's Garden)

Figure 1: Types of Fresh Produce Direct-Purchase Channels

\subsection{Prior Research on Consumer's Choice on Agricultural Product via Direct Market}

\subsubsection{Significance of Consumer's Choice on Direct-Purchase}

Table 1: South Korea Agricultural Produce Direct-Purchase Report and Projections

\begin{tabular}{|c|c|c|c|}
\hline Category & Y2015 Revenue & Y2021 Projection & Rate of Change \\
\hline Local Foods Direct Markets & 209.5 billion KRW & 350 billion KRW & $67.1 \%$ \\
\hline Produce Box (CSA) & 16.9 billion KRW & 27 billion KRW & $59.8 \%$ \\
\hline Direct Farm Markets & 178.7 billion KRW & 205 billion KRW & $14.7 \%$ \\
\hline Cyber Shopping & 1.2347 trillion KRW & 2.32 trillion KRW & $87.9 \%$ \\
\hline
\end{tabular}

Source: Ministry of Agriculture, Food and Rural Affairs (MAFRA) (2016a).

It is understood that consumers tend to prefer direct markets due to the belief that they can buy fresh, highquality produce. The specific options that consumers face when directly purchasing agricultural goods are offline farmer markets, local foods direct markets, produce boxes and online direct markets. This means that consumers have various substitute goods apart from the norm of indirectly purchasing fresh produce though existing distribution channels.

The Ministry of Agriculture, Food and Rural Affairs reports revenue and projections for each of these types of markets as below (MAFRA, 2016a).

As of 2015, cyber shopping had massed for a large portion of revenue and also had the highest rate of change by 2021 . Relatively, direct farm markets had a lower growth rate which can be seen as reflecting the development of ICT.

\subsubsection{Deciding Factors on Consumers' Choices on Agricultural Produce Direct Purchasing}

Prior research on consumers' choice of direct agricultural produce purchasing has primarily focused on the choice between indirect and direct marketing of existing retailers - studies addressed the deciding factors that influenced consumers' preferences of direct marketing. These previous studies tended to be categorized into two groups: studies that analyzed consumers who used fresh produce direct purchasing and studies that compared influential factors on consumers choosing between indirect and direct marketing.

According to studies that analyzed attributes of consumers who purchase via direct markets showed that demographic factors, socio-economic factors and personal preferences were important characteristics that put them apart from general consumers. Stated in a research on residents in Delaware, US by Gallons et al. (1997), differences were found in spending, shopping frequency, product preferences, information on direct marketing, advertisements, product quality and store interior. According to Bond, Thilmany and Bond (2006) which analyzed American consumers online, differences were found in produce quality, freshness, value, packaging and convenience. Onianwa, Mojica and Wheelock (2006) which researched consumers in Alabama reported difference in produce freshness, extrinsics, variety, price, convenience of shopping, payment promptness, store interior and location. A survey of New Jersey consumers by Govindasamy et al. (1998) showed deciding factors to be quality, 
variety and convenience, while Connell et al. (1986) who researched residents of Pennsylvania found freshness, quality, variety, price and atmosphere to be reasons why consumers prefer farmers' markets.

In Ontario, Canada, Hébert (2011) interviewed local residents and saw that environment-friendly awareness, support for local economy, freshness and quality initiated local produce purchases but convenience, price and locality, in turn, interfered.

And Rehman and Selvaraj (2013), who analyzed Indian consumers, reported that friendliness, freshness, variety, convenience, cost, purchase frequency, distance and product quality influences purchasing behavior. Skulskis and Girgžiene (2013) who studied Lithuanian consumers saw that the consumer's faith in the product's quality was the most important factor.

Park and Kim (2001), who analyzed consumer behavior in the Busan Nonghyup permanent stores found close distance, trust in Nonghyup, low prices, various products and quality were main motivations for using the stores.

Prior studies on consumer choices between indirect and direct agricultural markets state that through the discrete choice model, product quality, personal preferences, demographic factors and economic factors influence behavior. Govindasamy and Nayga, Jr. (1997), who inquired consumers in New Jersey's Pick-Your-Own Farms (PYO), roadside stands, farmers' markets and direct farm markets found, through the logit model, that respondents whose income ranges from \$40,000 \$59,000 USD had a lower chance of choosing PYO farms and a higher chance of buying from roadside stands, whereas respondents with an income lower than \$40,000 USD had higher chances of choosing roadside stands and farmers' markets. Also, consumers who emphasize freshness and those under the age of 65 had a higher response rate for roadside stands. Consumers living in the city and nearby outskirts had higher chances of choosing farmers' markets and women, more than men, had a higher rate in choosing direct farm markets. Onianwa, Wheelock and Mojica (2005) who performed logit analyses on consumers in Alabama presented that the interaction between level of education, presence of children and level of income had a significant influence on consumers' selection. Additionally, Zepeda \& Li (2006) who conducted probit analyses on American consumers found attitudes towards the product such as price, interest in cooking, demographic factors like age and region and economic factors such as household income influenced choices on local foods.

Jekanowski et al. (2000) who conducted telephone surveys of consumers in Indiana analyzed, through the ordered probit model, consumer behavior on a scale from 'unlikely', 'neutral to somewhat likely' and 'highly likely'. As a result, product quality, household income and length of residence had positive influences whereas men with higher levels of education where less likely to buy fresh produce from direct markets. Lastly, Bond, Thilmany and Bond (2009), who incorporated data from USNFO (US National Family Opinion Organization) and the multinomial logit model to measure 'direct never', 'direct always' or 'direct occasionally', found store attributes, product attributes, knowledge of product and credibility of information to have significant influences on direct market purchasing.

Table 2: Previous literatures on a preference of direct trade in agriculture foods

\begin{tabular}{|c|c|c|c|}
\hline Study & Region & $\begin{array}{c}\text { Research } \\
\text { Method }\end{array}$ & Factors \\
\hline $\begin{array}{c}\text { Govindasamy \& Nayga, } \\
\text { Jr. (1997) }\end{array}$ & New Jersey, USA & logit model & income, age, sex, region \\
\hline $\begin{array}{c}\text { Onianwa, Wheelock \& } \\
\text { Mojica (2005) }\end{array}$ & Alabama, USA & logit model & education, children, income \\
\hline Zepeda \& Li (2006) & USA & probit model & price, attitude, age, region, income \\
\hline $\begin{array}{c}\text { Jekanowski et al. (2000) } \\
\text { Bond, Thilmany \& Bond } \\
\text { (2009) }\end{array}$ & Indiana, USA & $\begin{array}{c}\text { ordered logit } \\
\text { model }\end{array}$ & $\begin{array}{c}\text { quality, income, education, length of } \\
\text { residence }\end{array}$ \\
\hline $\begin{array}{c}\text { Bavorova, Unay-Gailhard, } \\
\text { Lehberger(2015) }\end{array}$ & East Germany & $\begin{array}{c}\text { multinomial logit } \\
\text { model }\end{array}$ & $\begin{array}{c}\text { the characteristics of the store, the } \\
\text { characteristics of the goods, the } \\
\text { reliability of education and } \\
\text { information about food; }\end{array}$ \\
\hline $\begin{array}{c}\text { Shafiwu, Donkoh, \& } \\
\text { Alhassan (2018) }\end{array}$ & Burkina Faso & $\begin{array}{c}\text { multinomial logit } \\
\text { model }\end{array}$ & $\begin{array}{c}\text { price, reliability, safety, accessibility } \\
\text { to the store }\end{array}$ \\
\hline
\end{tabular}

In addition, Bavorova, Unay-Gailhard and Lehberger (2015), who surveyed East German residents, presented that the price, reliability, safety and accessibility to stores had a significant positive impact on the frequency of purchases at farm shops. Shafiu, Donkoh and Alhassan (2018), who surveyed of consumers in Burkina Faso in 
Africa addressed that vegetables sold at a stall had been more preferred over vegetables sold at supermarkets. And the number of family members and knowledge of vegetable markets had a significant positive impact on the preference, however, a purchase frequency had a negative impact significantly.

\subsection{Literature Review and Differentiation of this Study}

Existing research has either, analyzed the differences of consumers who participated in purchasing from direct markets with those who did not or compared the selection of direct and indirect markets through the binary logit model. Though a few previous studies have used the multinomial logit model to evaluate deciding factors that influence direct market purchasing, these studies have been limited to direct-purchase or not, or a frequency research of 'always', 'sometimes' purchasing from direct markets. Strictly speaking, since the dependent variables of 'doesn't purchase from direct markets', 'uses direct markets sometimes' and 'always uses direct markets' are ordinal variables, it is more appropriate to use the ordered probit model in such cases.

This study differs from prior studies in the following aspects. First, it uses the multinomial logit model to interpret Korean consumers' deciding factors on direct market options - previous research emphasized more on the American and Indian consumers' choices and frequency. Second, this study attempts to secure robustness by including product attribute, store attribute and personal attributes of consumers in the analysis model. Some studies, such as Bond, Thilmany and Bond (2009), analyzed the frequency of purchasing from direct markets through the multinomial logit model but did not include all related variables and separately analyzed store attribute, product attribute, knowledge of product and credibility of information. Such analysis results have limitations since results may vary if all related variables are to be included, and hence cannot guarantee such robustness.

\section{Methodology and Research Methods}

\subsection{Theories and Analytic Frame}

As seen through prior overseas research, it is clear that 'product attributes' such as freshness, credibility, variety, price and packaging have significant influences on consumer behavior. It has also been stated that 'store attributes' such as convenience of shopping, speed of transaction, atmosphere of store and location also have significant influences but there is no research regarding this on Korean consumers. Therefore, this study will examine the following hypotheses:

H1: Each product attribute will influence choice of direct market purchasing channels.

H2: Each store attribute will influence choice of direct market purchasing channels.

This study will utilize the multinomial logit model to analyze the effects of 'product attributes' and 'store attributes' on agricultural direct marketing.

This study puts the selection of direct marketing channels as the dependent variable with 'online direct marketing' as the reference group. 'Direct farm markets', 'local foods direct markets', 'produce boxes (CSA)' are selections between the method. The dependent variables consist of 'product attribute' with variety, price, credibility, packaging and 'store attribute' with transaction convenience, store interior (website design), location accessibility (swift delivery shipping for online stores). In addition, with reference to prior research, controlled variables are demographic labels such as 'gender', 'age', 'region' and economic factors such as 'income', 'spending cost' and 'usage frequency'.

The multinomial logit model is used to verify the factors that influence the choice of a specific substitute in the presence of various substitutes (Long, 1997: 149). Of the various substitutes, this study defines 'online direct marketing' as the reference group or base category. The multinomial logit model executes dependent variables without hierarchy and order. The binomial logit model is based on the assumption that the dependent variable has a binomial distribution, where the multinomial logit model is based on the assumption that the dependent variable has a multinomial distribution.

With the explanatory variable as $\mathrm{x}$, the probability that the results of the dependent variable will be $\mathrm{Y}=\mathrm{m}$ is $\mathrm{P}(\mathrm{Y}=\mathrm{m} \mid \mathrm{x})=\pi_{m}(x) \cdot \pi_{m}(x)$ can be expressed as a function of the bounded linear of dependent variables $x^{\prime} \beta_{m}$. As the probability cannot be negative, the exponential of $x^{\prime} \beta_{m}$ will be taken as $\exp \left(x^{\prime} \beta_{m}\right)$. The sum of probabilities of this being a single variable, $\sum_{j=1}^{g} \exp \left(x^{\prime} \beta_{j}\right)$, cannot be 1 . If $\exp \left(x^{\prime} \beta_{m}\right)$ is divided by $\sum_{j=1}^{g} \exp \left(x^{\prime} \beta_{j}\right)$ to make the sum of probabilities equal to 1 , the probability of the results of the dependent variable being $Y=m$ is as below. 


$$
\begin{aligned}
& \pi_{m}\left(x_{i}\right)=P\left(Y_{i}=m \mid x_{i}\right) \\
& =\frac{\exp \left(x_{i^{\prime}} \beta_{m}\right)}{\sum_{j=1}^{g}} \exp \left(x_{i}{ }^{\prime} \beta_{j}\right)
\end{aligned}
$$

In the multinomial logit model, one of the g amount of coefficient vectors is constrained to 0 , in which the category of the constrained coefficient vector is referred to as the reference category. If category $\mathrm{r}$ becomes the reference category, the $r$-th coefficient vector $\beta_{r}$ is restricted as 0 and $\exp \left(x^{\prime}{ }_{i} \beta_{r}\right)=\exp \left(x^{\prime}{ }_{i} 0\right)=1$. Therefore, the above equation (1) is converted to equation (2) below.

$$
\begin{aligned}
\pi_{m\left(x_{i}\right)=} \frac{\exp \left(x_{\left.i^{\prime} \beta_{m}\right)}\right)}{1+\sum_{j \neq r}} \exp \left(x_{i}^{\prime} \beta_{j}\right) \\
\pi_{r}\left(x_{i}\right)=1-\sum_{j \neq r} \quad \pi_{j}\left(x_{i}\right)
\end{aligned}
$$

In the multinomial logit model, the Maximum Likelihood Estimation of coefficient vectors $\beta^{\prime} s, \widehat{\beta}^{\prime} s$, becomes the input of coefficient vector $\beta^{\prime} s$ maximum likelihood function. On the assumption that the data is independent , the likelihood function is set as the following equation (Long, 1997: 157).

$$
\mathrm{L}\left(\beta_{1, \ldots,}, \beta_{\mathrm{g}} \mid X\right)=\prod_{m=1}^{g} \quad \prod_{Y=m} \quad \frac{\exp \left(x_{i^{\prime}} \beta_{m}\right)}{\sum_{j=1}^{g} \exp \left(x_{i^{\prime}} \beta_{j}\right)}
$$

The $\Pi_{Y_{i}=m}$ above, means the product of all data with $Y_{i}=m$. The final step of this analysis is to estimate the coefficient vectors that maximize the likelihood function taking natural logarithms in the equation above. In this case, the estimated coefficient vector does not indicate the effect of explanatory variables on $\mathrm{P}(\mathrm{Y}=\mathrm{m}) 1 \mathrm{but}$ explains the influence on selecting $\mathrm{P}(\mathrm{Y}=\mathrm{m})$ of base category, $\mathrm{P}(\mathrm{Y}=\mathrm{r})$ and $\mathrm{m}$.

\subsection{Measurement of Data and Variables}

\subsubsection{Data}

The Ministry of Agriculture, Food and Rural Affairs conducted a survey on the current state and satisfaction of consumers' use of agricultural produce direct purchasing in order to establish policies to vitalize these direct markets. The survey, conducted by MAFRA and commissioned by Focus Company, was carried out from May $25^{\text {th }}$ to June $10^{\text {th }}, 2015$ through systemized online questionnaires. Sample size was 643 consumers who purchase from fresh produce direct markets - excluding 11 invalid responses, margin of error is $\pm 3.86 \% \mathrm{p}$ at $95 \%$ confidence level (MAFRA, 2015).

\subsubsection{Measurement of Major Variables}

\subsubsection{Measurement of Dependent Variable}

This study established 'online direct markets' as the reference group (base category) since it is the most used channel and sets 'direct farm markets', 'local foods direct markets' and 'produce boxes (CSA)' as the outcome group.

\subsubsection{Measurement of Independent Variable}

First, 'product attributes' were measured as subjective factors perceived by the consumers. Productrelated attributes that consumers identified were variety, price, credibility, freshness and packaging. Consumers were asked to measure their impressions on a 5-point scale, '(1) very dissatisfied, (2) dissatisfied, (3) neutral, (4) satisfied, (5) very satisfied'.

Next, 'store attributes' were measured for both offline and online markets. These were diversified as transaction convenience, store interior (website design) and location accessibility (shipping for online stores). Respondents were also asked to answer on a scale of 1 to 5, '(1) very dissatisfied, (2) dissatisfied, (3) neutral, (4) satisfied, (5) very satisfied'.

\subsubsection{Measurement of Controlled Variable}

For demographic characteristics, 'gender' was used as the dummy variable with male being 1 and female being 0 . The age range of respondents was measured as (1) 29 and under, (2) 30-39, (3) 40-49, (4) 50-59, (5) 60 and

1 Hence, $\pi_{m}(x)$ 
over'. Place of residence was also used with dummy variable with metropolitan region (Seoul, Incheon, Gyeonggi) being the standard to central region (Daejeon, Gangwon, Chungbuk, Chungnam, Sejong), Honam region (Gwangju, Jeonbuk, Jeonnam, Jeju) and Yeongnam (Busan, Daegu, Ulsan, Gyeongbuk, Gyeongnam).

Next, economic factor of income was divided into '(1) $1.50 \mathrm{M} \mathrm{KRW}$ and under, (2) $1.5 \sim 3 \mathrm{M} \mathrm{KRW}$, (3) $3 \sim 4.5 \mathrm{M}$ $\mathrm{KRW}$, (4) 4.5 6M KRW, (5) 6 7.5M KRW, (6) 7.5 9M KRW, (7) $9 \mathrm{M} \mathrm{KRW}$ and above'. Average usage frequency was measured by '(1) Once every 3 months, (2) Once every 2 months, (3) One a month, (4) Once every 2 weeks, (5) Once a week, (6) More than twice a week'. And lastly, average spending cost was measured in KRW for each time the consumer purchased at the direct market.

\section{Results and Analysis}

\subsection{Significant General Statistics}

\subsubsection{Basic Attributes of Respondents}

The distribution of the basic attributes of sample size can be seen in Table 2. For method of direct-purchase, o nline direct market had the most respondents with 210 (33.23\%) followed by direct farm market with 209 (33.07 $\%$ ) and local foods direct market 160 (25.32\%), produce boxes (CSA) $53(8.39 \%)$ respectively.

For gender, women accounted for the majority with 341 respondents (53.96\%) and men took up 291 (46.04\%). As for age range, a majority of respondents were in their 30s (246, 38.92\%), followed by 40s (181, 28.94\%), 20 and under $(103,16.30 \%), 50 \mathrm{~s}(86,13.61 \%)$ and 60 and above being $2.53 \%$ with 16 surveyors. More than half of the sample size resided in the metropolitan areas $(392,62.03 \%)$ followed by Yeongnam $(146,23.10 \%)$, Honam $(54,8.54 \%)$ and Central (40, 6.33\%).

For income, most of the respondents earned 3M to 4.5M KRW (187, 29.59\%) followed by 4.5M to 6M KRW $(144,22.73 \%)$ and last was $1.5 \mathrm{M}$ to $3 \mathrm{M} \mathrm{KRW}(97,15.35 \%)$. Most respondents used direct markets once a month $(176,27.85 \%)$ with once every 2 weeks $(148,23.42 \%)$ and once a week $(141,22.31 \%)$ following.

Table 2: Key Specifications of Respondents

\begin{tabular}{|c|c|c|c|c|c|c|c|}
\hline \multicolumn{2}{|c|}{ Classification } & \multirow{2}{*}{$\begin{array}{c}\begin{array}{c}\text { Frequency } \\
\text { (\# of } \\
\text { respondents) }\end{array} \\
209\end{array}$} & \multirow{2}{*}{$\begin{array}{c}\begin{array}{c}\text { Proportion } \\
(\%)\end{array} \\
33.07\end{array}$} & \multicolumn{2}{|c|}{ Classification } & \multirow{2}{*}{$\begin{array}{c}\begin{array}{c}\text { Frequency } \\
\text { (\# of } \\
\text { respondents) }\end{array} \\
291\end{array}$} & \multirow{2}{*}{$\begin{array}{c}\begin{array}{c}\text { Propor- } \\
\text { tion } \\
(\%)\end{array} \\
46.04\end{array}$} \\
\hline \multirow{4}{*}{$\begin{array}{l}\text { Method of Direct- } \\
\text { Purchase }\end{array}$} & $\begin{array}{c}\text { Direct Farm } \\
\text { Market }\end{array}$ & & & \multirow[b]{2}{*}{ Gender } & Male & & \\
\hline & $\begin{array}{c}\text { Local Foods } \\
\text { Direct } \\
\text { Market }\end{array}$ & 160 & 25.32 & & Female & 341 & 53.96 \\
\hline & $\begin{array}{l}\text { Online } \\
\text { Direct } \\
\text { Market } \\
\end{array}$ & 210 & 33.23 & \multirow{5}{*}{ Age } & $\begin{array}{l}29 \& \\
\text { under }\end{array}$ & 103 & 16.30 \\
\hline & $\begin{array}{l}\text { Produce Box } \\
\text { (CSA) }\end{array}$ & 53 & 8.39 & & $30-39$ & 246 & 38.92 \\
\hline \multirow{4}{*}{ Region } & Metropolitan & 392 & 62.03 & & $40-49$ & 181 & 28.64 \\
\hline & Central & 40 & 6.33 & & $50-59$ & 86 & 13.61 \\
\hline & Yeungnam & 146 & 23.10 & & $\begin{array}{l}60 \text { and } \\
\text { above }\end{array}$ & 16 & 2.53 \\
\hline & Honam & 54 & 8.54 & \multirow{5}{*}{ Income } & $\begin{array}{l}1.5 \mathrm{M} \\
\mathrm{KRW} \\
\text { and } \\
\text { under }\end{array}$ & 32 & 5.06 \\
\hline \multirow{4}{*}{$\begin{array}{l}\text { Average Usage } \\
\text { Frequency }\end{array}$} & $\begin{array}{c}\text { Once every } 3 \\
\text { months }\end{array}$ & 61 & 9.65 & & $\begin{array}{c}1.5 \sim 3 \mathrm{M} \\
\text { KRW }\end{array}$ & 97 & 15.35 \\
\hline & $\begin{array}{c}\text { Once every } 2 \\
\text { months }\end{array}$ & 50 & 7.91 & & $\begin{array}{c}3 \sim 4.0 \mathrm{M} \\
\text { KRW }\end{array}$ & 187 & 29.59 \\
\hline & $\begin{array}{l}\text { Once a } \\
\text { month }\end{array}$ & 176 & 27.85 & & $\begin{array}{c}4.5 \sim 6 \mathrm{M} \\
\text { KRW }\end{array}$ & 144 & 22.73 \\
\hline & $\begin{array}{c}\text { Once every } 2 \\
\text { weeks }\end{array}$ & 148 & 23.42 & & $\begin{array}{c}6 \sim 7.5 \mathrm{M} \\
\text { KRW }\end{array}$ & 78 & 12.34 \\
\hline
\end{tabular}




\begin{tabular}{|c|c|c|c|c|c|c|c|}
\hline & Once a week & 141 & 22.31 & & $\begin{array}{c}7.5 \sim 9 \mathrm{M} \\
\text { KRW }\end{array}$ & 53 & 8.39 \\
\cline { 2 - 7 } & $\begin{array}{c}\text { More than } \\
\text { twice a week }\end{array}$ & 56 & 8.86 & & $\begin{array}{c}9 \mathrm{M} \\
\text { KRW } \\
\text { and } \\
\text { above }\end{array}$ & 41 & 6.49 \\
\hline
\end{tabular}

\subsubsection{Descriptive Statistics of Major Variables and Comparison of Difference Direct Markets}

Table 3: Descriptive Statistics of Major Variables

\begin{tabular}{|c|c|c|c|c|c|c|}
\hline \multicolumn{2}{|c|}{ Variable } & \multirow{2}{*}{$\begin{array}{c}\text { Observed Value } \\
632\end{array}$} & \multirow{2}{*}{$\begin{array}{c}\text { Mean } \\
3.665\end{array}$} & \multirow{2}{*}{$\begin{array}{c}\begin{array}{c}\text { Standard } \\
\text { Deviation }\end{array} \\
0.724\end{array}$} & \multirow{2}{*}{$\begin{array}{c}\text { Min. Value } \\
1\end{array}$} & \multirow{2}{*}{$\frac{\text { Max. Value }}{5}$} \\
\hline \multirow{5}{*}{$\begin{array}{l}\text { Product } \\
\text { Attribute }\end{array}$} & Variety & & & & & \\
\hline & Price & 632 & 3.714 & 0.742 & 1 & 5 \\
\hline & Credibility & 632 & 3.911 & 0.711 & 1 & 5 \\
\hline & Freshness & 632 & 3.981 & 0.663 & 1 & 5 \\
\hline & Packaging & 632 & 3.609 & 0.770 & 1 & 5 \\
\hline \multirow{3}{*}{$\begin{array}{c}\text { Store } \\
\text { Attribute }\end{array}$} & $\begin{array}{l}\text { Transaction } \\
\text { Convenience }\end{array}$ & 632 & 3.530 & 0.829 & 1 & 5 \\
\hline & Interior Design & 632 & 3381 & 0.754 & 1 & 5 \\
\hline & $\begin{array}{c}\text { Location } \\
\text { Accessibility }\end{array}$ & 632 & 3.581 & 0.790 & 1 & 5 \\
\hline \multicolumn{2}{|c|}{ Average Spending } & 632 & $53,155.940$ & $52,279.430$ & 1,000 & 500,000 \\
\hline
\end{tabular}

When examining the major continuous variables in the descriptive statistics of this study, from product attributes, freshness had the highest mean of 3.981 with credibility at 3.911 , price at 3.714 , variety at 3.665 and packaging at 3.609 in said order. For store attributes, location accessibility had the highest mean with 3.581 followed by transaction convenience with 3.530 and interior design with 3.381. Also, average spending costs were from $1,000 \mathrm{KRW}$ to $500,000 \mathrm{KRW}$ with the mean being 53,155.940KRW.

Table 4: Comparison on product and store attribute for difference methods of direct market

\begin{tabular}{|c|c|c|c|c|c|c|c|}
\hline \multicolumn{3}{|c|}{ Variable } & $\begin{array}{l}\text { Direct } \\
\text { Farm }\end{array}$ & $\begin{array}{c}\text { Local Foods } \\
\text { Direct }\end{array}$ & $\begin{array}{l}\text { Online } \\
\text { Direct }\end{array}$ & $\begin{array}{l}\text { Produce Box } \\
\text { (CSA) }\end{array}$ & $\begin{array}{c}\text { F-test } \\
\text { (p-value) }\end{array}$ \\
\hline \multirow{9}{*}{$\begin{array}{l}\text { Product } \\
\text { Attribute }\end{array}$} & \multirow{2}{*}{ Variety } & Mean & $3.78^{b}$ & $3.61^{b}$ & $3.58^{a}$ & $3.72^{b}$ & \multirow{2}{*}{$\begin{array}{c}3.21 \\
(0.023)\end{array}$} \\
\hline & & Std Dev & 0.68 & 0.72 & 0.75 & 0.77 & \\
\hline & \multirow{2}{*}{ Price } & Mean & $3.93^{c}$ & $3.45^{a}$ & $3.72^{b}$ & $3.62^{b}$ & \multirow{2}{*}{$\begin{array}{c}13.62 \\
(0.000)\end{array}$} \\
\hline & & Std Dev & 0.68 & 0.78 & 0.71 & 0.71 & \\
\hline & \multirow{2}{*}{ Credibility } & Mean & $3.91^{a}$ & $3.93^{a}$ & $3.81^{a}$ & $4.25^{b}$ & \multirow{2}{*}{$\begin{array}{c}5.49 \\
(0.001)\end{array}$} \\
\hline & & Std Dev & 0.64 & 0.73 & 0.76 & 0.65 & \\
\hline & \multirow{2}{*}{ Freshness } & Mean & $4.07^{b}$ & $3.99^{b}$ & $3.84^{a}$ & $4.17^{b}$ & \multirow{2}{*}{$\begin{array}{c}6.01 \\
(0.001)\end{array}$} \\
\hline & & Std Dev & 0.63 & 0.68 & 0.67 & 0.61 & \\
\hline & Packaging & Mean & $3.49^{a}$ & $3.56^{a}$ & $3.70^{b}$ & $3.89^{b}$ & 5.19 \\
\hline
\end{tabular}




\begin{tabular}{|c|c|c|c|c|c|c|c|}
\hline & & Std Dev & 0.79 & 0.74 & 0.75 & 0.75 & $(0.002)$ \\
\hline \multirow{6}{*}{$\begin{array}{c}\text { Store } \\
\text { Attribute }\end{array}$} & \multirow{2}{*}{$\begin{array}{l}\text { Transaction } \\
\text { Convenience }\end{array}$} & Mean & $3.26^{a}$ & $3.60^{b}$ & $3.70^{b}$ & $3.72^{b}$ & \multirow{2}{*}{$\begin{array}{c}12.34 \\
(0.000)\end{array}$} \\
\hline & & Std Dev & 0.91 & 0.75 & 0.76 & 0.69 & \\
\hline & \multirow{2}{*}{$\begin{array}{l}\text { Interior } \\
\text { Design }\end{array}$} & Mean & $3.28^{a}$ & $3.49^{a}$ & $3.32^{a}$ & $3.66^{b}$ & \multirow{2}{*}{$\begin{array}{c}5.32 \\
(0.001)\end{array}$} \\
\hline & & Std Dev & 0.78 & 0.79 & 0.70 & 0.65 & \\
\hline & \multirow{2}{*}{$\begin{array}{c}\text { Location } \\
\text { Accessibility }\end{array}$} & Mean & $3.43^{a}$ & $3.48^{a}$ & $3.74^{b}$ & $3.85^{b}$ & \multirow{2}{*}{$\begin{array}{c}8.47 \\
(0.000)\end{array}$} \\
\hline & & Std Dev & 0.80 & 0.79 & 0.76 & 0.69 & \\
\hline
\end{tabular}

Post-hoc (Scheffe) results $\mathrm{a}<\mathrm{b}<\mathrm{c}$

An ANOVA test was performed to determine whether there was a difference between 'product attribute' and 'store attribute', Scheffe's test was used as post-hoc since it is most conservative. For 'product attribute', variety for online direct market was the lowest while other methods were similar. Price for local foods direct market had the lowest mean whereas direct farm market had the highest. Credibility for produce box (CSA) was the highest and the rest were similar. Freshness for direct farm market and produce box (CSA) was high while local foods direct market and online direct market were relatively low. For packaging, produce box (CSA) and online direct market was high while direct farm market and local foods direct market turned out to be low. For 'store attribute', transaction convenience for direct farm market was the lowest while other methods were quite similar. Interior design for produce box (CSA) was the highest but the other were similar. Location accessibility was highest for produce box (CSA) and online direct market but relatively lower for direct farm market and local foods direct market.

\subsection{Interpretation of Multinomial Logit Analysis Results}

Table 5 shows the results of using the multinomial logit model to analyze factors influencing consumer behav ior when choosing method of agricultural produce direct market. For relative risk reduction (RRR) in the results, Odds Ratio was used to compare between alternatives (Cameron \& Trivedi, 2009: 486). This makes it easier to compare the selection probability of other variables compared to the reference group. For example, when comparing the probability of selecting 'local foods direct market' and produce box (CSA)' to the reference of 'online direct market', if the probability is less than 1.0 then consumers prefer the reference group and hence are more likely to choose 'online direct market'. If the probability is higher than 1.0, the consumer has a higher chance of selecting 'local foods direct market' and 'produce box (CSA)' over 'online direct store'.

First, when examining the sub-variable of 'product attributes', as variety increases so does the probability to select 'direct farm market' over 'online direct store' but there were no significant findings for the other substitutes. In Bond, Thilmany and Bond (2009)'s study, variety was not a significant factor but there is a chance that consumers would select direct farm markets because multiple producers bring and sell diverse fresh produce.

Next, the more reasonable the price, the possibility of choosing 'direct farm market' over 'online direct store' was significantly high but the probability of choosing 'local foods direct market' and 'produce box (CSA)' was significantly lower. These results conflict with Bond, Thilmany and Bond (2009)'s study but it can be inferred that direct farm stores require less cost because it does not need land for permanent stores or cost to manage a website and therefore are able to provide produce at lower costs and thus making consumers select this method. On the other hand, as Hébert (2011) specified, price is an obstacle for local food direct markets and produce boxes (CSA).

And higher credibility showed to increase the probability of selecting 'produce boxes (CSA)' over 'online direct market' in a statistically significant manner but showed no significance for other methods. It can be surmised that since produce boxes require a subscription fee to be paid to the farmers' association, the safety and quality of the fresh produce can be guaranteed compared to the other methods and thus have a higher probability of being selected.

Better freshness of the product had significant increase in probability for selecting 'direct farm market' and 'local foods direct market' over 'online direct store'; probability of selecting 'produce box (CSA) was also high but not significant. This result corresponds to Bond, Thilmany \& Bond (2009)'s study and it can be said that consumers tend to select direct farm markets and local foods direct stores to acquire freshly picked goods. 
Table 5: Multinomial Logit Model Results

\begin{tabular}{|c|c|c|c|c|c|c|c|}
\hline & & \multicolumn{2}{|c|}{ Direct Farm Markets } & \multicolumn{2}{|c|}{$\begin{array}{c}\text { Local Foods Direct } \\
\text { Markets }\end{array}$} & \multicolumn{2}{|c|}{ Produce Boxes (CSA) } \\
\hline & & b/se & RRR & b/se & RRR & b/se & RRR \\
\hline \multirow{5}{*}{$\begin{array}{l}\text { Product } \\
\text { Attribute }\end{array}$} & Variety & $\begin{array}{c}0.522 * * * \\
(0.183) \\
\end{array}$ & 1.685 & $\begin{array}{c}0.064 \\
(0.190) \\
\end{array}$ & 1.066 & $\begin{array}{l}-0.108 \\
(0.266) \\
\end{array}$ & 0.897 \\
\hline & Price & $\begin{array}{c}0.527^{* * *} \\
(0.185)\end{array}$ & 1.695 & $\begin{array}{c}-0.773^{* * *} \\
(0.185) \\
\end{array}$ & 0.462 & $\begin{array}{c}-0.734 * * * \\
(0.261)\end{array}$ & 0.480 \\
\hline & Credibility & $\begin{array}{c}0.022 \\
(0.195) \\
\end{array}$ & 1.022 & $\begin{array}{c}0.323 \\
(0.205) \\
\end{array}$ & 1.381 & $\begin{array}{l}0.893^{* * *} \\
(0.308)\end{array}$ & 2.442 \\
\hline & Freshness & $\begin{array}{c}0.653 * * * \\
(0.209) \\
\end{array}$ & 1.921 & $\begin{array}{c}0.593 * * * \\
(0.218) \\
\end{array}$ & 1.809 & $\begin{array}{c}0.489 \\
(0.313) \\
\end{array}$ & 1.631 \\
\hline & Packaging & $\begin{array}{l}-0.353 * \\
(0.183) \\
\end{array}$ & 0.702 & $\begin{array}{l}-0.391 * * \\
(0.191) \\
\end{array}$ & 0.676 & $\begin{array}{c}0.033 \\
(0.271) \\
\end{array}$ & 1.034 \\
\hline \multirow{3}{*}{$\begin{array}{c}\text { Store } \\
\text { Attribute }\end{array}$} & $\begin{array}{c}\text { Transaction } \\
\text { Convenience } \\
\end{array}$ & $\begin{array}{c}-0.798 * * * \\
(0.166)\end{array}$ & 0.450 & $\begin{array}{l}-0.007 \\
(0.184)\end{array}$ & 0.993 & $\begin{array}{l}-0.204 \\
(0.260)\end{array}$ & 0.815 \\
\hline & $\begin{array}{l}\text { Interior } \\
\text { Design }\end{array}$ & $\begin{array}{c}0.073 \\
(0.181) \\
\end{array}$ & 1.076 & $\begin{array}{c}0.553 * * * \\
(0.193)\end{array}$ & 1.738 & $\begin{array}{c}0.431 \\
(0.273) \\
\end{array}$ & 1.538 \\
\hline & $\begin{array}{c}\text { Location } \\
\text { Accessibility }\end{array}$ & $\begin{array}{c}-0.670 * * * \\
(0.169) \\
\end{array}$ & 0.512 & $\begin{array}{c}-0.661 * * * \\
(0.180) \\
\end{array}$ & 0.516 & $\begin{array}{l}-0.143 \\
(0.253) \\
\end{array}$ & 0.867 \\
\hline \multicolumn{2}{|c|}{ Gender } & $\begin{array}{l}-0.081 \\
(0.224)\end{array}$ & 0.923 & $\begin{array}{c}0.281 \\
(0.231)\end{array}$ & 1.324 & $\begin{array}{c}0.163 \\
(0.330)\end{array}$ & 1.177 \\
\hline \multicolumn{2}{|c|}{ Age } & $\begin{array}{l}-0.144 \\
(0.113)\end{array}$ & 0.866 & $\begin{array}{l}-0.143 \\
(0.117)\end{array}$ & 0.867 & $\begin{array}{l}-0.272 \\
(0.168)\end{array}$ & 0.762 \\
\hline \multirow{3}{*}{ Region } & Central & $\begin{array}{l}-0.705 \\
(0.476) \\
\end{array}$ & 0.494 & $\begin{array}{l}-0.702 \\
(0.481) \\
\end{array}$ & 0.495 & $\begin{array}{l}-0.277 \\
(0.627) \\
\end{array}$ & 0.758 \\
\hline & Yeungnam & $\begin{array}{c}0.131 \\
(0.268) \\
\end{array}$ & 1.140 & $\begin{array}{c}0.044 \\
(0.283) \\
\end{array}$ & 1.045 & $\begin{array}{c}0.061 \\
(0.395) \\
\end{array}$ & 1.063 \\
\hline & Honam & $\begin{array}{c}0.036 \\
(0.435) \\
\end{array}$ & 1.036 & $\begin{array}{l}0.916 * * \\
(0.409) \\
\end{array}$ & 2.500 & $\begin{array}{l}-0.424 \\
(0.814)\end{array}$ & 0.654 \\
\hline \multicolumn{2}{|c|}{ Income } & $\begin{array}{l}-0.049 \\
(0.074) \\
\end{array}$ & 0.952 & $\begin{array}{c}0.019 \\
(0.077) \\
\end{array}$ & 1.019 & $\begin{array}{l}0.192 * \\
(0.105) \\
\end{array}$ & 1.211 \\
\hline \multicolumn{2}{|c|}{$\begin{array}{c}\text { Average Usage } \\
\text { Frequency }\end{array}$} & $\begin{array}{c}0.364 * * * \\
(0.084) \\
\end{array}$ & 1.438 & $\begin{array}{c}0.361 * * * \\
(0.089) \\
\end{array}$ & 1.434 & $\begin{array}{c}0.373^{* * *} \\
(0.131) \\
\end{array}$ & 1.452 \\
\hline \multicolumn{2}{|c|}{ Average Spending } & $\begin{array}{c}1.49 \mathrm{e}-7 \\
(2.12 \mathrm{e}-6)\end{array}$ & 1.000 & $\begin{array}{l}-2.11 \mathrm{e}-6 \\
(2.24 \mathrm{e}-6)\end{array}$ & 1.000 & $\begin{array}{l}-3.10 \mathrm{e}-6 \\
(3.50 \mathrm{e}-6) \\
\end{array}$ & 1.000 \\
\hline \multicolumn{2}{|c|}{ Constant } & $\begin{array}{c}-1.114 \\
(0.932)\end{array}$ & 0.328 & $\begin{array}{c}-0.438 \\
(0.956)\end{array}$ & 0.645 & $\begin{array}{c}-5.522 * * * \\
(1.462)\end{array}$ & 0.004 \\
\hline \multicolumn{2}{|c|}{ Observed Value } & \multicolumn{6}{|c|}{632} \\
\hline \multicolumn{2}{|c|}{ LR $\chi^{2}(\mathrm{p}$-value $)$} & \multicolumn{6}{|c|}{$242.70(0.000)$} \\
\hline \multicolumn{2}{|c|}{ Log likelihood } & \multicolumn{6}{|c|}{-692.454} \\
\hline \multicolumn{2}{|c|}{ Pseudo $\mathrm{R}^{2}$} & \multicolumn{6}{|c|}{0.149} \\
\hline
\end{tabular}

$* \mathrm{p}<0.1, * * \mathrm{p}<0.05, * * * \mathrm{p}<0.01$

With better packaging, probability of selecting 'direct farm market' and 'local foods direct market' over 'online direct market' was significantly low; choosing 'produce box (CSA)' was high but not significant. This is similar to Bond, Thilmany \& Bond (2009)'s research that packaging does have an important influence on direct market selection. Online direct markets may pay more attention to packaging due to the damage that comes from shipping and handling, but direct farm markets and local foods direct markets tend to pay less attention to packaging and focus more on the freshness of produce.

For 'store attribute' as a sub-variable, as transaction convenience was high the probability of choosing 'direct farm market' other 'online direct market' was significantly low; the other methods were low as well but not 
statistically significant. This can be seen as similar to the study of Onianwa, Mojica \& Wheelock (2006) that the ease of transaction process influences the direct market. This is most likely because cash is mainly used as the transaction method in direct farm markets and credit cards or mobile payment are not widely accepted.

The higher the interior design (website design) is, the probability that consumers will choose 'local foods direct market' was significantly high but the other methods were not significant. In the case of local foods direct stores, since a lot of effort is put into the structure and arrangement of the area, it can be surmised that consumers would more likely prefer.

The better location accessibility (speedy delivery for online), the probability to choose 'direct farm market' and 'local foods direct market' over 'online direct market' was significantly low; probability to select 'produce box (CSA)' was high but insignificant. It is assumed to be less preferred as online direct stores have the convenience of delivering to the doorsteps of the consumer's house whereas if a consumer were to purchase by other methods, they would have to transport the products themselves.

Among the controlled variables, consumers in the Honam region were more likely to select 'local foods direct market' over 'online direct market'. This is most likely to have sprouted from the local food movement to develop local economy (Hébert, 2011). For Korea, it can be said that such movements have been actively spread and local government-level support ordinances have been enacted (Ju, 2015).

With higher income, the probability of consumers selecting 'produce box (CSA)' over 'online direct market' is statistically high and significant. Though, in Bond, Thilmany \& Bond (2009)'s study, income did not have an influential role on usage frequency, as produce boxes require an upfront, subscription fee it can be presumed that consumers with higher incomes tend to prefer this method.

And as usage frequency increased, there was a significantly high probability that consumers will choose 'direct farm market', 'local foods direct market' and 'produce box (CSA)' over 'online direct market'. This can be concurred as related to Gallons et al. (1997)'s study where the frequency of shopping influenced direct-purchase. Although online direct shopping enables mass amounts to be purchased in a single transaction, since the other methods require small amounts to be purchased frequently, this could lead consumers to have a high probability of selection.

\section{Conclusion and Limitations}

This study analyzed the deciding factors that influence a consumer's choice of agriculture produce direct market channel. Korea's agricultural distribution structure comprises complexities arousing from multiple intermediaries who risk obstacles such as seasonality, storage periods and price fluctuations due to market supply and demand. These complexities brought about cost issues where wholesalers bought produce from the area of origin at a low price in which were then sold at quite high prices in more populated areas. Therefore, the government intervened in order to ensure adequate prime costs to farmers and enable consumers access to highquality products at reasonable prices. Recently, the government is also making an effort to facilitate smoother transactions by easing regulations regarding fresh produce direct-purchasing. As stated previously, efforts such as reducing credit card processing fees in local foods direct markets, giving income tax reductions on produce purchased in direct-markets and securing locations along rivers/streams or parks for direct-markets are being made. However, such measures can be assessed as none more than stop gap policies that do not fully consider consumers' choices and the factors behind them.

From MAFRA's statistics and results from this study, it can be seen that Korean consumers generally tend to prefer online direct markets among the various channels. This finding comes hand in hand with Korea's rapid entrance into information society through development in ICT and high-speed internet. It is worthy to notice that offline methods such as direct farm markets, local food direct markets and produce boxes (CSA) had higher credibility, as seen in Table 4, compared to untact, online markets. The reliability between producer and consumer in regard to product safety is a significant consideration as junk food was labeled as one of the 'Four Evils' by the previous government. In light of this tendency, the results of this study carry important policy implications.

This study has the following three contributions. First, results showed that transportation convenience had a negative influence on direct farm markets and local foods farm markets, but this is mainly because the locations are situated on the outskirts of the city where consumers have lower accessibility. Thus, marketing strategies are needed to increase the accessibility of offline stores and it is also necessary to consider these consumers and provide spaces near residential areas or placed with convenient transportation access by a government or local government.

Second, although the government is trying to ease regulations on credit card processing fees within local foods direct markets; this study shows that negative impact due to such fees are targeting direct farm markets. Considering that Korea's smartphone penetration rate is over $90 \%$, it is more efficient for direct markets to support mobile payments through smartphone devices. In relation to this, practically marketing strategies utilizing 
FinTech or mobile currency, such as Kakao Pay, Naver Pay, Samsung Pay, Zero Pay, and Seoul Pay, are also required.

Third and last, though the government is trying to implement income tax reductions for products bought from direct markets, this study shows significance of income tax on only produce boxes (CSA). Hence, the effects of this implementation would only be slight. If income tax reduction is associated to price, caution is necessary since direct farm markets and local foods farm markets have opposite marks compared to produce boxes (CSA). Since the estimated growth rate for both local foods farm markets and produce boxes (CSA) are much higher than direct farm markets, it is discernable that this policy, only directed towards direct farm markets, has not accurately reflected the current trend.

While this study has significance in which it incorporated empirical analysis on the deciding factors impacting fresh produce direct trade, it has the following limitations due to being secondary data. First, it does not reflect the subjective preference of consumers by omitting organic products, material content such as vitamins, color, etc. Next, it did not consider additional demographic factors such as level of education, number of household members and presence of children. Additionally, it excluded consumers who did not choose fresh produce direct-purchase and therefore does not analyze differences between consumers who prefer direct-purchase and indirect-purchase.

In retrospect, future studies will need to carry out extensive research including all consumers, who not only purchase directly but also indirectly, with a diversified set of comprehensive questions.

\section{Reference}

Bavorova, M., Unay-Gailhard, I., \& Lehberger, M. (2015). Who buys from farmers' markets and farm shops: The case of Germany. International Journal of Consumer Studies, 40(1), 107-114.

Bond, J. K., Thilmany, D., \&Bond, C. A. (2006). Direct marketing of fresh produce: Understanding consumer purchasing decisions. Choices, 21(4), 229-235.

Bond, J. K., Thilmany, D., \& Bond, C. A. (2009). What influences consumer choice of fresh produce purchase location. Journal of Agricultural and Applied Economics, 41(1), 61-74.

Brown, A. (2002). Farmers' market research 1940-2000: An inventory and review. American Journal of Alternative Agriculture, 17(4), 167-176.

Cameron, A. C., and Trivedi, P. K. (2005). Microeconometrics using data. College Station, Texas: Stata Press.

Connell, C. M., Beierlein, J. G., \& Vroomen. H. (1986). Consumer preferences and attitudes regarding fruit and vegetable purchases from direct market outlets. Paper No.185. Department of Agricultural Economics and Rural Sociology, Pennsylvania State University, University Park.

Gallons, J., Toensmeyer, U. C., Bacon, J. R., \& German, C. L. (1997). An analysis of consumer characteristics concerning direct marketing of fresh produce in Delaware: A case study. Journal of Food Distribution Research, 28(1), 98-106.

Govindasamy, R., \& Nayga, Jr., R. M. (1997). Determinants of farmer-to-consumer direct market visits by type of facility: A logit analysis. Agricultural and Resource Economics Review, 26(1), 31-38.

Govindasamy, R., Zurbriggen, M., Italia, J., Adelaja, A., Nitzsche, P., \& Van Vranken, R. (1998). Farmers' markets: consumer trends, preferences, and characteristics. New Jersey Agriculture Experiment Station, Cook College, Rutgers, New Brunswick.

Hébert, M. (2011). Examining Current Research on Local Food: A Review. Studies by Undergraduate Researchers at Guelph, 4(2), 88-92.

Jekanowski, M. D., Williams II, D. R., \& Schick, W. A. (2000). Consumers' willingness to purchase locally produced agricultural products: An analysis of an Indiana survey. Agricultural and Resource Economics Review, 29(8), 43-53.

$\mathrm{Ju}$, Sang-Hyeon (2015). An analysis and policy implication of the local food success factors. The Korean Journal of Local Government Studies, 19(3), 291-315.

Kim, Kyung Hee \& Park, Duk Byeong (2012). Relationship among purchase motivation, satisfaction, and loyalty of consumers in farm direct markets. Journal of the Korean Society of Dietary Culture, 27(4), 331-339

Kim, Myunghwan, Kim, Byoungryul, Jeong, Eunmee, Seung Ryeul Shin, \& Choi, Ji-Hyeon (1998). Revitalization of direct trading of agricultural and livestock products. Korea Rural Economic Institute, Policy Research Report, P27.

Korea Food Service News (2019). Increase safety and symbiosis between urban and agricultural communities in the midst of expanding public concepts. 01.16 .

Korea JoongAng Daily (2015). News in News $<265>$ Direct trading of agricultural products. 02.26.

Lee, Da Ye \& Lee, Hee Yeon (2016). Factors affecting the farmer-to-consumer direct marketing and its influence on the sale increase of agricultural products. Journal of Rural Development, 39(1), 89-116. 
Lee, Hee-Chan (2009). Analyzing demand for farmer-to-consumer direct marketing and size of expenditures. Korean Journal of Agricultural Management and Policy, 36(1), 49-79.

Long, J. S. (1997). Regression models for categorical and limited dependent variables. London: Sage Publications.

Ministry of Agriculture, Food and Rural Affairs (2015). Survey report on policy experience of direct trading policy of agricultural products.

Ministry of Agriculture, Food and Rural Affairs (2016a). Establishing a basic plan for promoting the use of local agricultural products and revitalizing their direct trade: Creating a distribution system in which producers and consumers trust and coexist, Press Release.

Ministry of Agriculture, Food and Rural Affairs (2016b). The basic plan for promoting the use of local agricultural products and activating their direct trade.

Ministry of Agriculture, Food and Rural Affairs (2017). Promotion of regulatory reform to revitalize direct trading of agricultural products, Press Release.

Onianwa, O., Mojica M., \& Wheelock, G. (2006). Consumer characteristics and views regarding farmers markets: An examination of on-site survey data of Alabama consumers. Journal of Food Distribution Research, 37(1), 119-125.

Onianwa, O., Wheelock, G., \& Mojica, M. (2005). An analysis of the determinants of farmer-to-consumer directmarket shoppers. Journal of Food Distribution Research, 36(1), 130-134.

Park, Cheol \& Kim, Hyung Tak (2001). A study on the consumer's evaluation of the agricultural product outlet store owned by agricultural cooperative. Journal of Marketing Management Research, 6(1), 85-104.

Rehman, S. U., \& Selvaraj, M. (2013). Factors influencing customer preference towards Uzhavar Santhais(farmers' market) in Namakkal district Tamil Nadu. International Business Management, 7(2), 84-90.

Shafiwu, A. B., Donkoh, S. A., \& Alhassan, H. (2018). Consumers' preferred purchasing outlet of safer vegetables in Ouagadougou, Burkina Faso. Cogent Food \& Agriculture, 4(1), 1-16.

Skulskis, V., \& Girgžiene, V. (2013). Direct marketing and consumer trust in organic food products: Vilnius (Lithuania) Case. Journal of Agricultural Science and Technology, 3(2), 272-283.

Udimal, T. B. (2015). Factors influencing soybean producers' choice of marketing channels in the Saboba district of northern region, Ghana. Unpublished Master Thesis, Kwame Nkrumah University.

Zepeda, L., \& Li, J. (2006). Who buys local food. Journal of Food Distribution Research, 37(3), 1-11. 